\title{
POŚTA
}

TELEKOMUNIKÁCIE A

ELEKTRONICKY OBCHOD

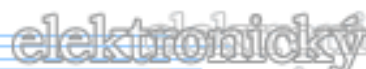

iseroi)

9. 1.5

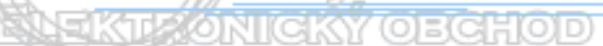

\section{BENCHMARKINGOVÉ POROVNÁVANIE SLUŽIEB ELEKTRONICKÉHO BANKOVNÍCTVA AKO EKOLOGICKEJ INOVÁCIE}

\author{
Erika Loučanová ${ }^{1}$
}

\begin{abstract}
The aim of the paper is benchmarking by comparing selected electronic banking services of Slovak banks as a form of eco-innovation with a focus on innovation in this sector. We point out the differences between the services offered in individual banks, which provide it within the portfolio of their services, as well as the identification of customer requirements. Based on the results, we can state that the customer has not largely mastered the innovations, but they are nevertheless very important from the perspective of the future.
\end{abstract}

Keywords: benchmarking, banking, electronic banking, ecological innovation, determinants of eco-innovation.

\section{Úvod}

V súčasnej dobe digitálneho sveta, meniaceho sa prostredia, v ktorom sa neustále zvyšujú nároky zo strany spotrebitel'ov, rastie aj tempo rozvoja elektronických inovácií. Neustále zlepšovanie, porovnávanie sa s konkurenciou vyvoláva potrebu prinášat' klientom nové alternatívy. Ako raz povedal Steve Jobs ,Inovácia predstavuje rozdiel medzi lídrom a nasledovnikom,“ [1] preto je snahou firiem realizovat' inovácie a tým uspokojovat' ich potreby.

Pojem inovácia pochádza z latinského slova nova, novitas, ktorý slúži na označenie niečoho nového. Bol po prvýkrát použitý v oblasti technických vied. Slovník obchodnej angličtiny z roku 1989 od Longmana definuje slovo inovácia ako „l'ubovol'ný námet alebo vylepšenú metódu, produkujúcu úžitkovú hodnotu. Lubovol'ná zmena vo výrobných metódach, poskytujúca výrobcovi, ktorý ju prvý prinesie na trh, výhodu oproti jeho konkurentom, čo môže viest' $k$ dočasnému monopolu “ [2].

Pojem inovácia označuje tiež výrobok alebo proces, teda akýkol'vek nový druh podnikovo-subjektívneho predmetu, ktorý je dôležité nielen vynájst', ale rovnako ho aj presadit' $\mathrm{v}$ rámci podniku, ale aj navonok. Treba podotknút', že sa nejedná iba o podnikovoindividuálnu novinku. Dôležitú úlohu zohrávajú aj problémy v oblasti zavedenia a presadenia tejto novinky [3].

Podnikatelia sa neustále snažia vytvárat' hodnoty a prispievat' niečím novým, pričom neberú ohl'ad na svoju individuálnu motiváciu, ktorou môžu byt' peniaze, túžba po poznaní, ale aj zvedavost'. Úspešné firmy sa neuspokoja iba so zdokonal'ovaním alebo modifikáciou niečoho existujúceho. Podniky si vytyčujú vysoké ciele a pokúšajú sa vytvárat' odlišné a nové hodnoty, odlišné a nové uspokojenie, existujúce zdroje skombinovat' do produktívnejšej a novej konfigurácie alebo premenit' materiál na zdroj. Vysoký obsah novosti môže byt'

\footnotetext{
${ }^{1}$ Ing. Erika Loučanová, PhD., Technická univerzita vo Zvolene

e-mail: loucanova@tuzvo.sk
} 
zdrojom dlhodobej konkurenčnej výhody. Z tohto pohl'adu môžeme inovácie charakterizovat' ako „zmenu výnosnosti zdrojov alebo zmenu hodnôt a uspokojení, ktoré z daných zdrojov získava spotrebitel'“ [4].

Za inovatívne označuje Čimo [4] mnohé výrobky, služby, procesy, technológie, postupy, organizačné štruktúry zlepšujúce kvalitu života a tie, ktoré majú radikálny význam. Taktiež tie, ktoré sú nové alebo nie sú nové, ale majú novú formu, prípadne sú kombináciou už existujúcich foriem.

Elektronická komunikácia sa stáva pomaly už bežnou súčast'ou života l’udí, preto sa banky snažia využit' túto formu čo najlepšie, nakol'ko šetrí čas, peniaze a v neposlednom rade aj životné prostredie, čím predstavuje ekologickú inováciu. Pričom pod pojmom ekologické inovácie chápeme akékol'vek inovácie zamerané na výrazný a viditel'ný pokrok smerom k ciel'u udržatel'ného rozvoja, a to prostredníctvom znižovania dopadov na životné prostredie, alebo dosiahnutia efektívnejšieho a zodpovednejšieho využitia prírodných zdrojov vrátane energií. Pomerne často sa používa definícia ekologických inovácií skupiny výskumníkov Maastrichtskej univerzity, podl'a ktorých ekologická inovácia je produkcia, aplikácia alebo využívanie tovarov, služieb, výrobných procesov, organizačných štruktúr, manažérskych alebo podnikatel'ských modelov, ktoré sú nové pre firmu alebo užívatel'ov, a ktorých výsledky smerujú k zníženiu environmentálnych rizík, znečistenia a negatívnych dopadov využívania zdrojov v porovnaní s existujúcimi alternatívami [5].

Mechanizmy ekoinovácií predstavujú metódy, ktoré sa uplatňujú v ekoinovačných ciel'och. Medzi základné štyri metódy patria:

$>$ modifikácia,

$>$ redizajn,

$>$ alternatívy (alebo substitúcie),

$>$ vytvorenie úplne nového produktu, procesu, organizácie alebo inštitúcie.

Dopadmi ekoinovácií sa chápu vplyvy na životné prostredie a sú výsledkom vzájomnej interakcie ekoinovačných ciel'ov a mechanizmov v určitom sociálno-technologickom prostredí [6].

Elektronické bankovníctvo využívajú klienti komerčných bánk už niekol'ko rokov, nakol'ko predstavuje jednoduchý prístup $\mathrm{k}$ financiám, ich prehl'ad a iné východy elektronického bankovníctva. Možnost' využit' domáce prostredie je pre mnohých nenahraditel'ná. Taktiež míňanie papiera pri realizácii bankových úkonov v kamennej pobočke, alebo strávit' drahocenný čas státím v zástupe klientov banky, je pre mnohých l’udí neprijatel'ná predstava a hlavne v súčasnej dobe pandémie COVIC-19 predstavuje vhodnú alternatívu bezpečia a rovnako ekologické riešenie administratívy.

$\mathrm{Aj}$ z tohto dôvodu sa budeme $\mathrm{v}$ našom príspevku zaoberat' benchmarkingovým porovnávaním služieb elektronického bankovníctva slovenských bánk. Pričom sa zameriame na vybrané druhy poskytovaných služieb a inovácie v elektronickom bankovníctva.

\section{Metodika}

Primárnou metódou príspevku je benchmarkingové porovnávanie založené na Kano modely. Kano model prostredníctvom 5 kategórií vnímanej kvality zo strany zákazníkov vyjadruje vzt’ah medzi stupňom ich spokojnosti a atribútmi kvality. Medzi tieto kategórie zarad'ujeme: jednorozmerové, atraktívne, povinné, protichodné a bezvýznamné atribúty produktov, ktoré tvoria kvalitu. Jednotlivé kategórie vnímanej kvality sa menia v súlade so životným cyklom - prechádzajú z bezvýznamných, cez atraktívne, jednorozmerové až po kategóriu povinných atribútov kvality. Zákazník môže v tomto okamihu určitý atribút kvality považovat' za atraktívny, ale v budúcnosti ho môže zaradit' medzi povinné. Táto zákonitost' nemusí platit' pre všetky druhy produktov. Je dôležité si uvedomit', že vnímanie jednotlivých kategórií sa mení z časového hl'adiska. Súčasne platí, že atraktívne atribúty kvality vedú 
jednoznačne k spokojnosti zákazníkov. Je dôležité podotknút', že jednotlivé atribúty kvality vo svojej podstate predstavujú požiadavky, ktoré zákazníci kladú na produkt [7,8].

Metodika Kano modelu vychádza zo štyroch základných krokov, a to:

$>\quad$ identifikácia parametrov,

$>\quad$ zostavenie KANO dotazníka,

$>\quad$ dotazníkové opatrenia,

$>\quad$ vyhodnotenie a následná interpretácia.

V rámci prvého kroku sme identifikovali parametre prieskumu, ktoré predstavovali základné sledované parametre elektronického bankovníctva a inovácie v elektronickom bankovníctve, uvedené v tabul'ke 2, stĺpec sledované parametre.

Následne bol zostavený Kano dotazník, kde na základe metodiky Kano modelu, boli otázky koncipované pozitívne a negatívne na každý sledovaný parameter. Respondenti mali možnost' odpovedat' na škále 1 až 5, čím vyjadrili svoj silný súhlas až silný nesúhlas s koncipovanými otázkami, ktoré služby velektronickom bankovníctve využíva a ktoré služby v rámci internetbankingu sú podl'a neho najmenej potrebné.

V rámci dotazníkových opatrení bol prieskum realizovaný osobným dopytovaním slovenských respondentov. Celkový počet respondentov dosiahol počet 1576, čím bola splnená minimálna vzorka respondentov vypočítaná na základe nasledovného vzt'ahu (1):

$$
\mathrm{n}==\frac{z^{2} \frac{\alpha \pi}{2} * g^{2}}{F^{2}}=\frac{11.28^{2} * 0.26^{2}}{Q .07^{2}}
$$

$\mathrm{n}=1128$ respondentov

kde:

$$
z_{1}^{2}
$$

$\mathrm{s}$ = štandardná odchýlka, vypočítaná na základe vzt'ahu $s=\sqrt{p x(1-F)}$

$\mathrm{p}=$ podiel znaku, ak podiel znaku nie je známy, používa sa hodnota 0,5

$\mathrm{H}=$ prípustné rozpätie chýb, alebo maximálna chyba odhadu, pre nás 7\% [9].

Po samotnej realizácii prieskumu prostredníctvom KANO dotazníka sa pristúpi $\mathrm{k}$ vyhodnoteniu KANO modelu. KANO model vyhodnocuje jednotlivé otázky na základe krížového pravidla, kde určíme špecifikované vlastnosti odpovede, ako atraktívne (A), povinné $(\mathrm{M})$, presne opačné $(\mathrm{R})$, jednorozmerné $(\mathrm{O})$, nejednoznačné $(\mathrm{Q})$ alebo nemajú vplyv (I) podl'a tabul'ky 1.

\begin{tabular}{|c|c|c|c|c|c|c|}
\hline & \multicolumn{5}{|c|}{ Negatívne koncipovaná otázka } \\
\hline & & 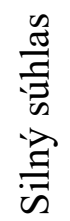 & 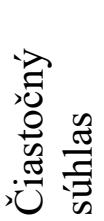 & 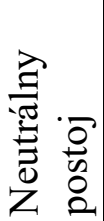 & 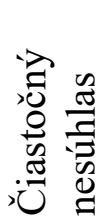 & 空急 \\
\hline \multirow{5}{*}{ 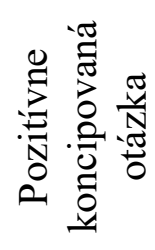 } & Silný súhlas & Q & A & A & A & $\mathrm{O}$ \\
\hline & Čiastočný súhlas & $\mathrm{R}$ & I & I & I & $\mathrm{M}$ \\
\hline & Neutrálny postoj & $\mathrm{R}$ & I & $\mathrm{I}$ & I & $\mathrm{M}$ \\
\hline & Čiastočný nesúhlas & $\mathrm{R}$ & $\mathrm{I}$ & I & I & $\mathrm{M}$ \\
\hline & Silný nesúhlas & $\mathrm{R}$ & $\mathrm{R}$ & $\mathrm{R}$ & $\mathrm{R}$ & $\mathrm{Q}$ \\
\hline
\end{tabular}

Tabul'ka $1 \quad$ KANO model na vyhodnotenie špecifických požiadaviek zákazníka [7]

Pri vyhodnocovaní odpovedí teda postupujeme, nasledovne: ak respondent nám odpovedal na pozitívne formulovanú otázku so silným súhlasom a na negatívne formulovanú 
otázku čiastočným nesúhlasom, môžeme danú vlastnost' špecifikovat' ako atraktívnu pre zákazníka. Následne početnosti alebo percentuálny podiel jednotlivých odpovedí podl'a KANO modelu zhrnieme do tabul'ky ako pomocného prostriedku pre samotnú identifikáciu špecifických vlastností produktov vo vzt’ahu k spokojnosti zákazníka, kde najväčšie zastúpenia identifikovaných špecifických vlastností produktu určuje výsledný postoj sledovanej skupiny respondentov k identifikovaným požiadavkám na produkt.

Kategórie požiadaviek na sledované parametre, ktoré majú vplyv na spokojnost' zákazníkov, môžeme na základe uvedeného charakterizovat' nasledovne [10]:

povinné (M - must-be) - sú požiadavky, ktoré zákazník považuje za samozrejmé a automaticky ich očakáva. Je možné ich označit' aj ako základné, z čoho vyplýva, že ak nie sú splnené, zákazník bude vel’mi nespokojný, ale vzhl'adom $\mathrm{k}$ tomu, že tieto požiadavky považuje zákazník za samozrejmé, ak sú splnené, nezaoberá sa nimi. Ich identifikovanie má značný význam, pretože zákazník si okamžite uvedomí ich absenciu, čo sa prejaví v jeho maximálnej nespokojnosti.

atraktívne (A - attractive) - sú požiadavky, ktoré majú jednoznačný vplyv na spokojnost' zákazníka. Jedná sa o požiadavky, ktoré zákazník neočakáva, zčoho vyplýva, že ak nie sú splnené, neprejaví sa to v nespokojnosti zákazníka.

$>$ jednorozmerové $(\mathrm{O}$ - one-dimensional $)$ - sú požiadavky, ktorých splnenie vedie k spokojnosti zákazníka a ich nesplnenie naopak k nespokojnosti. Existuje priama lineárna závislost' medzi splnením jednorozmerových požiadaviek a spokojnost’ou zákazníka, teda čím vyššia je miera splnenia požiadaviek, tým spokojnejší je zákazník.

$>$ bezvýznamné (I - indifferent) - sú požiadavky, ktoré nijakým spôsobom neovplyvňujú spokojnost' ani nespokojnost' zákazníka. Tieto požiadavky nie sú pre zákazníka rozhodujúce, a preto sa nezaujíma o to, či sú alebo nie sú splnené.

protichodné ( $\mathrm{R}$ - reverse) - sú požiadavky, pre ktoré platí, že čím vyššia je miera ich splnenia, tým sa prehlbuje nespokojnost' zákazníka.

Ďalej pre vykonanie benchmarkingového porovnávania sme jednotlivým identifikovaným kategóriám požiadaviek priradili váhy, ktoré boli stanovené na základe charakteristiky jednotlivých požiadaviek, tak ako to definujú viaceré odborné literatúry, a to nasledovne:
povinné požiadavky $(\mathrm{M})$ majú váhu 3,
atraktívne požiadavky (A) majú váhu 2,
jednorozmerové požiadavky $(\mathrm{O})$ majú váhu 1 ,
bezvýznamné požiadavky (I) majú váhu 0 ,
protichodné požiadavky $(\mathrm{R})$ majú váhu $-1[7]$.

Na základe prenásobenia váhou príslušnej požiadavky získame požadovanú hodnotu pre zákazníka a konečným sčítaním všetkých požiadaviek získame celkovú hodnotu danej inovácie z pohl'adu klienta, resp. zákazníka.

\section{Benchmarkingové porovnávanie služieb elektronického bankovníctva}


$\mathrm{Na}$ základe uvedenej metodiky bol realizovaný prieskum prostredníctvom Kano modelu, kde vzorku respondentov tvorilo 1576 respondentov. Z hl'adiska štruktúry vzorky respondentov sme sa v dotazníku zamerali na ich pohlavie, vek a spôsob, ktorým najčastejšie komunikujú s bankou a pristupujú k svojmu účtu. Podl'a veku sme umožnili respondentom zaradit' sa do jednej zo štyroch kategórií, pričom najnižšia veková kategória začínala 15 rokov, a to $\mathrm{z}$ dôvodu, že práve $\mathrm{v}$ tomto veku si klienti môžu zakladat' prvé študentské účty. Z hl'adiska štruktúry vzorku tvorilo 47,27 \% mužov a 57,73 \% žien. Čo sa týka prístupu $\mathrm{k}$ účtu a najčastejšej formy komunikácie s bankou z prieskumu vyplynulo, že $60,66 \%$ respondentov najčastejšie využíva elektronické bankovníctvo, z toho $50 \%$ prostredníctvom internet bankingu a 10,46 \% cez smart banking, a 39,54 \% respondentov si zájde osobne na kamennú pobočku banky. Z výsledkov je zrejmé, že ženy najradšej využívajú služby prostredníctvom kamennej pobočky ( $47,58 \%$ z celkového počtu žien), a to najmä vo vekovej kategórii 61 rokov a viac, $43,42 \%$ žien použiva internet banking a iba $9 \%$ smart banking. Až $53,95 \%$ mužov prevažne vo veku 27 - 40 rokov preferuje prácu so svojím účtom prostredníctvom internet bankingu, služby kamennej pobočky využíva 30,20 \% mužov a smart banking používa 15,85 \% mužov. Z respondentov, ktorí v dotazníku uviedli, že najčastejšie používajú smart banking, je až 70,60 \% mužov a tieto mobilné bankové aplikácie sú oblúbené vo vekovej kategórii 15 - 26 rokov. Kamenná pobočka ja oblúbenou vol'bou vo vekovej kategórii 61 a viac rokov.

Na základe získaných údajov a ich spracovania podl'a metodiky prostredníctvom krížového pravidla uplatneného $\mathrm{v}$ rámci metodiky $\mathrm{v}$ tabul'ke 1 , boli identifikované požiadavky respondentov na sledované parametre. V rámci základných sledovaných parametrov, sme ako povinnú požiadavku, ktorú zákazník považuje za samozrejmú a automaticky ich očakáva, identifikovali možnost' platby a sledovania pohybu na účte. Ako atraktívnu požiadavku, ktorá má jednoznačný vplyv na spokojnost' zákazníka, sme identifikovali vedenie účtu zadarmo, a ako jednorozmerové požiadavky, ktoré môžeme charakterizovat' ako priamu lineárnu závislost' medzi splnením jednorozmerových požiadaviek a spokojnost'ou zákazníka, sme identifikovali prehlad' účtov a história platieb, trvalé príkazy a prehlad' cez mobil alebo tablet. Platobné šablóny, zobrazenie zostatkov a vývoja produktov $\mathrm{v}$ grafoch, zoznam pobočiek a bankomatov neovplyvňuje spokojnost', resp. nespokojnost' respondentov. Ostatné sledované parametre mali na respondentov protichodný vplyv, čo znamená, že čím vyššia je miera ich splnenia, tým sa prehlbuje nespokojnost' zákazníka.

Uvedené výsledky sme zhrnuli do výslednej tabul'ky a následne za jednotlivé banky sme ich porovnali prostredníctvom benchmarkingového porovnávania služieb elektronického bankovníctva slovenských bánk, vid' tabul'ka 2.

V uvedenej tabul'ke okrem spomínaných údajov, sledované parametre a identifikované požiadavky respondentov na sledované parametre, prostredníctvom Kano modelu, je uvedená váha každého parametra. Táto bola určená podl'a charakteristiky identifikovanej požiadavky respondentov. Čo predstavuje, že ak sledovaný parameter bol identifikovaný ako povinný a má značný význam na spokojnost' zákazníka, pretože zákazník si okamžite uvedomí ich absenciu, čo sa prejaví v jeho maximálnej nespokojnosti, tak jeho váha predstavuje najväčšiu váhu, t.j. 3, atraktívne požiadavky, ak majú jednoznačný vplyv na spokojnost' zákazníka, je im priradená váha 2, jednorozmerové požiadavky, ktorých splnenie vedie k spokojnosti zákazníka a ich nesplnenie naopak k nespokojnosti a majú lineárny charakter, predstavujú váhu 1 , nemajúce vplyv váhu 0 a protichodné, pre ktoré platí, že čím vyššia je miera ich splnenia, tým sa prehlbuje nespokojnost' zákazníka, majú váhu -1.

Následne pre sledované banky pôsobiace na slovenskom bankovom trhu, bol určený výskyt sledovaných parametrov, pod čím rozumieme, či daná banka poskytuje túto službu v rámci elektronického bankovníctva alebo nie. Pri sledovanom parametre - vedenie účtu zadarmo - sme uviedli jeho výskyt pri všetkých bankách, nakol'ko každá banka poskytuje 
takúto službu, avšak pri dodržaných určitých špecifických podmienok. Sčítaním výskytu inovácií v rámci jednotlivých bánk sme určili počet inovácií, ktoré jednotlivé banky ponúkajú svojim zákazníkom. Prenásobením výskytu poskytovanej služby (sledovaného parametra) váhou sledovaného parametra sme určili hodnotu sledovaného parametra pre respondentov. Sčítaním jednotlivých hodnôt sledovaných parametrov v rámci jednotlivých bánk sme určili výslednú hodnotu pre zákazníka vnímanú respondentmi. Rovnako boli určené aj hodnoty inovácií pre zákazníka a hodnota základných parametrov elektronického bankovníctva pre zákazníka.

$\mathrm{Na}$ základe uvedeného a výsledkov je spracované benchmarkingové porovnávania služieb elektronického bankovníctva slovenských bánk, vid' tabul'ka 2, kde môžeme vidiet', že benchmarkom v oblasti inovácií elektronického bankovníctva je Tatra banka, nakol'ko na trhu poskytuje najväčší počet služieb, ktoré predstavujú inovácie, v celkovom počte 17 . Vo sfére internetového bankovníctva svojou ponukou inovácií vyniká, nakol'ko svojim klientom poskytuje najširšie spektrum možností narábania so svojím účtom. Od klasických možností platby a prehl'adu účtov, ktoré poskytuje každá banka, Tatra banka umožňuje klientom aj napríklad prihlasovat' sa pomocou tvárovej biometrie a mnohé iné funkcionality, ktoré však práve klienti hodnotia ako protichodné, a práve preto sa táto banka z pohl'du hodnoty pre zákazníka nachádza na poslednom miesta.

Benchmarkom v oblasti hodnoty skúmaných funkcionalít elektronického bankovníctva pre zákazníkov je Raiffensen banka, ktorá zákazníkom neponúka v podstate žiadne inovácie (neponúka žiadnu funkcionalitu elektronického bankovníctva predstavujúcu niektorú zo sledovaných inovácií), ale zameriava sa na uspokojovania ich základných požiadaviek, ktorá je na úrovni 4.

Z pohl'adu benchmarkingového porovnávania inovácií elektronického bankovníctva môžeme konštatovat', že zákazník neoceňuje význam inovácií, nakol'ko využíva predovšetkým základné operácie ako sú trvalé príkazy, prehl’ad účtov a história platieb a pod.. Inovácie si naši respondenti v značnej miere neosvojili, ako vyplýva z celkového hodnotenia, avšak nájdu sa aj respondenti, ktorí jednotlivé inovácie využívajú. Vo všeobecnosti môžeme povedat' že inovácie v elektronickom bankovníctve vyvolávajú u respondentov protichodné požiadavka, ktoré sú charakteristické tým, že čím vyššia ich miera splnenia, tým sa prehlbuje nespokojnost' zákazníka a vyvoláva v ňom odpor k zmene. Odpor k zmene, t.j. k inovácii, ako uvádza Slávik [11], je prirodzená reakcia a je súčast'ou procesu adaptácie na zmenu, na inováciu. Môžeme teda konštatovat', že väčšina inovácií elektronického bankovníctva, z pohl'adu životného cyklu, sa nachádzajú v uvádzacej fáze, pričom zákazníci sa s nimi ešte zoznamujú a iba odvážlivci ich využívajú. Odmietanie inovácií v uvádzacej fáze, potvrdzuje aj teória rozporu [12, 13]. Veber a kol. [14] uvádzajú, že v počiatočnej fáze inovácie predstavujú pre podnikatel'ský subjekt malé prínosy, nakol'ko ide o nový produkt, je potrebné aby si získal svoje miesto na trhu, oslovil zákazníkov a postupne bude prinášat' pre podnik požadovaný efekt $[15,16]$. 
Tabul'ka 2 Benchmarkingové porovnávanie ponuky elektronických služieb slovenských bánk

\begin{tabular}{|c|c|c|c|c|c|c|c|c|c|c|c|c|c|c|c|c|c|c|c|c|c|c|c|c|c|c|c|}
\hline & \multirow[b]{2}{*}{ Sledované parametre } & \multirow{2}{*}{\multicolumn{2}{|c|}{ Požiadavka|Váha }} & \multicolumn{2}{|c|}{ Poštová banka } & \multicolumn{2}{|c|}{ Tatra banka } & \multicolumn{2}{|c|}{ ČSOB } & \multicolumn{2}{|c|}{ SLSP } & \multicolumn{2}{|c|}{ VUB } & \multicolumn{2}{|c|}{ OTP } & \multicolumn{2}{|c|}{\begin{tabular}{|c|} 
UniCredit \\
\end{tabular}} & \multicolumn{2}{|c|}{ Raiffeisen bank } & \multicolumn{2}{|c|}{ Prima banka } & \multicolumn{2}{|c|}{ mBank } & \multicolumn{2}{|c|}{ Fio bank } & \multicolumn{2}{|c|}{365 banka } \\
\hline & & & & Viskyt & Hodnota & Vískyt & Hodnota & Vískyt & Hodnota & Visksyt & Hodnota & Vískyt & Hodnota & Vískyt & Hodnota & Vískyt & Hodnota & Viskyt & Hodnota & Viskkyt & Hodnota & Vískyt & Hodnota & Vískyt & Hodnota & Visksyt & Hodnota \\
\hline \multirow{16}{*}{ 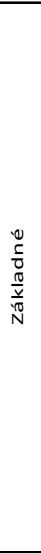 } & Platba a pohyby na úctoch & $M$ & 3 & 1 & 3 & 1 & 3 & 1 & 3 & 1 & 3 & 1 & 3 & 1 & 3 & 1 & 3 & 1 & 3 & 1 & 3 & 1 & 3 & 1 & 3 & 1 & 3 \\
\hline & Online nákup produktov & $R$ & -1 & 0 & 0 & 1 & -1 & 1 & -1 & 1 & -1 & 1 & -1 & 1 & -1 & 0 & 0 & 0 & 0 & 1 & -1 & 1 & -1 & 1 & -1 & 1 & -1 \\
\hline & Vedenie úćtu radarmo & A & 2 & 1 & 2 & 1 & 2 & 1 & 2 & 1 & 2 & 1 & 2 & 1 & 2 & 1 & 2 & 1 & 2 & 1 & 2 & 1 & 2 & 1 & 2 & 1 & 2 \\
\hline & Prehl'ad úctov a história platieb & 0 & 1 & 1 & 1 & 1 & 1 & 1 & 1 & 1 & 1 & 1 & 1 & 1 & 1 & 1 & 1 & 1 & 1 & 1 & 1 & 1 & 1 & 1 & 1 & 1 & 1 \\
\hline & Platobné šablóny & 1 & 0 & 1 & 0 & 1 & 0 & 1 & 0 & 1 & 0 & 1 & 0 & 1 & 0 & 1 & 0 & 1 & 0 & 1 & 0 & 1 & 0 & 1 & 0 & 0 & 0 \\
\hline & Trvalé príkazy & 0 & 1 & 1 & 1 & 1 & 1 & 1 & 1 & 1 & 1 & 1 & 1 & 1 & 1 & 1 & 1 & 1 & 1 & 1 & 1 & 1 & 1 & 1 & 1 & 1 & 1 \\
\hline & Nastavenie SMS a notifikácíí pohyboch na uúté & $R$ & -1 & 1 & -1 & 1 & -1 & 1 & -1 & 1 & -1 & 1 & -1 & 0 & 0 & 1 & -1 & 0 & 0 & 1 & -1 & 1 & -1 & 1 & -1 & 1 & -1 \\
\hline & SEPAinkaso & $R$ & -1 & 1 & -1 & 1 & -1 & 1 & -1 & 1 & -1 & 1 & -1 & 1 & -1 & 1 & -1 & 1 & -1 & 1 & -1 & 1 & -1 & 0 & 0 & 1 & -1 \\
\hline & Zobrazenie zostatkov a vivoja produktov v grafoch & 1 & 0 & 1 & 0 & 1 & 0 & 1 & 0 & 1 & 0 & 1 & 0 & 0 & 0 & 1 & 0 & 0 & 0 & 0 & 0 & 1 & 0 & 0 & 0 & 0 & 0 \\
\hline & Výpis z úcutu vo formáte PDF & $\mathrm{R}$ & -1 & 1 & -1 & 1 & -1 & 1 & -1 & 1 & -1 & 1 & -1 & 1 & -1 & 1 & -1 & 1 & -1 & 0 & 0 & 1 & -1 & 1 & -1 & 1 & -1 \\
\hline & Bilancia majetku a záväzkov & $R$ & -1 & 0 & 0 & 1 & -1 & 1 & -1 & 1 & -1 & 0 & 0 & 1 & -1 & 0 & 0 & 0 & 0 & 1 & -1 & 1 & -1 & 0 & 0 & 1 & -1 \\
\hline & Online nákup produktov - cer mobil alebo tablet & $R$ & -1 & 1 & -1 & 1 & -1 & 1 & -1 & 1 & -1 & 1 & -1 & 1 & -1 & 0 & 0 & 0 & 0 & 1 & -1 & 1 & -1 & 0 & 0 & 1 & -1 \\
\hline & Prehl'ad a história platieb - cez mobil alebo tablet & 0 & 1 & 1 & 1 & 1 & 1 & 1 & 1 & 1 & 1 & 1 & 1 & 1 & 1 & 1 & 1 & 1 & 1 & 1 & 1 & 1 & 1 & 1 & 1 & 1 & 1 \\
\hline & Platobné šablóny - cez mobil alebo tablet & $R$ & -1 & 1 & -1 & 0 & 0 & 1 & -1 & 0 & 0 & 0 & 0 & 0 & 0 & 1 & -1 & 1 & -1 & 1 & -1 & 0 & 0 & 1 & -1 & 0 & 0 \\
\hline & Trvalé prikazy - cez mobil alebo tablet & $R$ & -1 & 0 & 0 & 1 & -1 & 1 & -1 & 0 & 0 & 1 & -1 & 1 & -1 & 1 & -1 & 1 & -1 & 1 & -1 & 1 & -1 & 1 & -1 & 1 & -1 \\
\hline & Zoznam pobocièk/ bankomatov & 1 & 0 & 1 & 0 & 1 & 0 & 1 & 0 & 0 & 0 & 1 & 0 & 1 & 0 & 1 & 0 & 0 & 0 & 1 & 0 & 1 & 0 & 1 & 0 & 1 & 0 \\
\hline \multirow{21}{*}{$\begin{array}{l}\frac{0}{0} \\
\underline{n} \\
0 \\
\underline{.}\end{array}$} & Spending report & $R$ & -1 & 0 & 0 & 1 & -1 & 0 & 0 & 1 & -1 & 1 & -1 & 0 & 0 & 1 & -1 & 0 & 0 & 1 & -1 & 1 & -1 & 0 & 0 & 0 & 0 \\
\hline & Push notifikácie o pohyboch na účte & $R$ & -1 & 0 & 0 & 1 & -1 & 0 & 0 & 1 & -1 & 1 & -1 & 1 & -1 & 1 & -1 & 0 & 0 & 1 & -1 & 1 & -1 & 1 & -1 & 1 & -1 \\
\hline & Bezkontaktná platba mobilom & $R$ & -1 & 1 & -1 & 1 & -1 & 1 & -1 & 1 & -1 & 1 & -1 & 1 & -1 & 1 & -1 & 0 & 0 & 1 & -1 & 1 & -1 & 1 & -1 & 1 & -1 \\
\hline & Platba na tel. čislo & $R$ & -1 & 0 & 0 & 1 & -1 & 0 & 0 & 0 & 0 & 1 & -1 & 0 & 0 & 0 & 0 & 0 & 0 & 0 & 0 & 1 & -1 & 0 & 0 & 0 & 0 \\
\hline & Založenie úctu online & $R$ & -1 & 0 & 0 & 1 & -1 & 0 & 0 & 0 & 0 & 1 & -1 & 1 & -1 & 0 & 0 & 0 & 0 & 0 & 0 & 0 & 0 & 0 & 0 & 1 & -1 \\
\hline & Tvárová biometria & $R$ & -1 & 0 & 0 & 1 & -1 & 0 & 0 & 1 & -1 & 0 & 0 & 0 & 0 & 0 & 0 & 0 & 0 & 0 & 0 & 0 & 0 & 0 & 0 & 0 & 0 \\
\hline & Skener čiarovich kódov & $R$ & -1 & 1 & -1 & 1 & -1 & 1 & -1 & 1 & -1 & 1 & -1 & 1 & -1 & 1 & -1 & 0 & 0 & 1 & -1 & 1 & -1 & 1 & -1 & 1 & -1 \\
\hline & Skener QR kódov & $R$ & -1 & 1 & -1 & 1 & -1 & 1 & -1 & 1 & -1 & 1 & -1 & 1 & -1 & 1 & -1 & 0 & 0 & 1 & -1 & 1 & -1 & 1 & -1 & 1 & -1 \\
\hline & Skener IBAN-u & $R$ & -1 & 1 & -1 & 1 & -1 & 1 & -1 & 1 & -1 & 1 & -1 & 1 & -1 & 0 & 0 & 0 & 0 & 0 & 0 & 0 & 0 & 0 & 0 & 0 & 0 \\
\hline & Snimač odtlačkov prstov & $R$ & -1 & 0 & 0 & 1 & -1 & 1 & -1 & 1 & -1 & 1 & -1 & 1 & -1 & 1 & -1 & 0 & 0 & 1 & -1 & 1 & -1 & 1 & -1 & 1 & -1 \\
\hline & Výber z bankomatu mobilom & $R$ & -1 & 0 & 0 & 1 & -1 & 0 & 0 & 0 & 0 & 1 & -1 & 0 & 0 & 0 & 0 & 0 & 0 & 0 & 0 & 0 & 0 & 0 & 0 & 0 & 0 \\
\hline & Platba hodinkami & $R$ & -1 & 1 & -1 & 1 & -1 & 0 & 0 & 1 & -1 & 0 & 0 & 0 & 0 & 1 & -1 & 0 & 0 & 1 & -1 & 1 & -1 & 0 & 0 & 1 & -1 \\
\hline & Dobijanie kreditu cez Facebook & $R$ & -1 & 0 & 0 & 1 & -1 & 1 & -1 & 1 & -1 & 1 & -1 & 0 & 0 & 0 & 0 & 0 & 0 & 0 & 0 & 0 & 0 & 0 & 0 & 0 & 0 \\
\hline & Export transakcii do formátov CSV, XML & $R$ & -1 & 0 & 0 & 1 & -1 & 1 & -1 & 1 & -1 & 1 & -1 & 1 & -1 & 0 & 0 & 0 & 0 & 0 & 0 & 1 & -1 & 1 & -1 & 0 & 0 \\
\hline & Vypisy do úctonnictva & $R$ & -1 & 0 & 0 & 1 & -1 & 0 & 0 & 0 & 0 & 0 & 0 & 1 & -1 & 0 & 0 & 0 & 0 & 0 & 0 & 0 & 0 & 1 & -1 & 0 & 0 \\
\hline & Dávkové platby & $R$ & -1 & 0 & 0 & 1 & -1 & 1 & -1 & 0 & 0 & 1 & -1 & 1 & -1 & 0 & 0 & 0 & 0 & 0 & 0 & 1 & -1 & 1 & -1 & 0 & 0 \\
\hline & Správa vkladov v EUR -i : deposit & $R$ & -1 & 0 & 0 & 1 & -1 & 1 & -1 & 0 & 0 & 0 & 0 & 0 & 0 & 0 & 0 & 0 & 0 & 0 & 0 & 0 & 0 & 0 & 0 & 0 & 0 \\
\hline & Počet inovácií & se & & 5 & 2 & 17 & $\sum$ & 9 & 2 & 11 & $\infty$ & 13 & 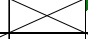 & 10 & $\sum$ & 7 & 2 & 0 & $\infty$ & 7 & 2 & 10 & 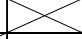 & 8 & 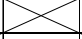 & 7 & 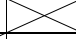 \\
\hline & Hodnota pre zákaznika & $\sum$ & & $\sum$ & -2 & 8 & -16 & $\sum$ & -9 & 2 & -9 & $\sum$ & -11 & $\sum$ & -8 & $\sum$ & -4 & $\infty$ & 4 & $\sum$ & -6 & 8 & -9 & $\sum$ & -5 & $\sum$ & -6 \\
\hline & Hodnota inovácii pre zákaznika & $\sum$ & & $\sum$ & -5 & 8 & -17 & 2 & -9 & 8 & -11 & $\sum$ & -13 & $\sum$ & -10 & 2 & -7 & $\sum$ & 0 & $\sum$ & -7 & 2 & -10 & 8 & -8 & $\sum$ & -7 \\
\hline & Hodnota základných parametrov pre zákaznika & $\sum$ & & 8 & 3 & 8 & 1 & $\infty$ & 0 & 8 & 2 & 8 & 2 & 8 & 2 & 8 & 3 & $\sum$ & 4 & $\sum$ & 1 & $\infty$ & 1 & 8 & 3 & 8 & 1 \\
\hline
\end{tabular}


Uvedené výsledky naznačujú, že inovácie v bankovom sektore sú tlačené technológiou a nie t'ahané dopytom, čo spôsobuje aj ich prvotný nezáujem o ponúkané inovácie. Tento model prístupu k inováciám „tlačené technológiou“ hovorí o tom, že podnikatel'ské subjekty využívajú poznatky vedcov, vynálezcov a inovátorov pre zvyšovanie pridanej hodnoty produktov a z pohl'adu dlhodobej perspektívy využitie týchto vedeckých objavov v praxi predstavuje pravdepodobný potenciál vodcovstva $\mathrm{v}$ oblasti podnikania, tak ako to uvádza Bačišin [17]. Stratégia vzniku takýchto inovácií je rovnako založená na potrebách a to potrebách vnútorných zákazníkov, potreby podnikatel'skej jednotky ako vyrábajúceho, resp. poskytujúceho subjektu a potrebách niektorých stakeholderov. Potreby vnútorných zákazníkov predstavujú požiadavky na vysokú technicko-ekonomickú úroveň, kvalitu, hospodárnost' a včasnost' odovzdaných produktov, polotovarov, služieb a informácií v nadväzujúcich a kooperujúcich vnútropodnikových výrobných, pomocných, obslužných, administratívne správnych a iných procesoch, predstavujú jadro vzt'ahov vnútrofiremných subjektov ako vnútorných zákazníkov. Ich podnikatel'ské chovanie sleduje naplnenie poslania a základných ciel'ov podnikatel'skej jednotky ako celku. Znamená to, že k potrebám a požiadavkám všetkých vnútropodnikových subjektov, ako vnútorných zákazníkov, patrí odstraňovanie nedostatkov a neefektívnosti, aj zvyšovanie technicko-ekonomickej úrovne ich organizačných štruktúr, procesov $\mathrm{v}$ nich prebiehajúcich a výstupov $\mathrm{z}$ nich preto, aby $\mathrm{v}$ rámci poslania základných ciel'ov podniku ako celku boli dosiahnuté maximálne hodnoty pre zákazníka u všetkých vymieňaných a kooperovaných vnútorných produktov firmy, t.j. každá zo skúmaných bánk z pohl'adu základných parametrov a funkcionalít zabezpečuje kladné hodnoty pre zákazníka (napríklad Tatra banka predstavuje z pohl'adu uspokojenia základných parametrov elektronického bankovníctva pre zákazníkov hodnotu 1), a inovácie ktoré sú tlačené technológiou, predstavujú negatívne hodnoty vnímané zákazníkmi, nakol'ko neuspokojujú a ani nepredstavujú ich potreby a je nevyhnutné ich osvojenie a adaptácia u zákazníkov (napríklad Tatra banka predstavuje z pohl’adu inovácí́ elektronického bankovníctva pre zákazníkov hodnotu až mínus 17). Obdobnú vyváženost' základných požiadaviek predstavujúcich naplnenie základných ciel'ov bánk (pozitívne hodnoty základných parametrov bankových funkcionalít pre zákazníkov), a tvorbu inovácií tlačených technológiou (negatívne hodnoty vnímania inovácií bankových funkcionalít zákazníkmi), môžeme sledovat' u všetkých bánk na slovenskom trhu, ako znázorňuje tabul'ka 2. Tieto potreby vnútorných zákazníkov sú tu chápané ako potreby a požiadavky relatívne autonómnych vnútropodnikových procesov a procesne štruktúrovaných výrobných jednotiek. Vytvárajú tak vel'mi husté pradivo vnútorných inovačných potrieb, ktoré sú saturované prevažne procesnými inováciami. V rámci bankového sektora práve digitalizácia poskytovania bankových služieb predstavuje tieto procesné inovácie so zameraním na maximalizáciu eliminácie papierov vytvárajúc inovácie šetrné k životnému prostrediu, t.j. ekologické inovácie predstavujúce zelené bankovníctvo. Nevyhnutnost' týchto ekologických inovácií tlačených technológiou je vel'mi významná, napriek tomu že u zákazníkov najskôr vyvolávajú odpor k zmene, čo potvrdzuje aj momentálna situácia, v ktorej sa nachádzame, ked’že sme súčast'ou pandémia ochorenia COVID-19. Práve v tomto období je dôležité zdržat' sa osobného kontaktu, čo nám umožňuje práve elektronické bankovníctvo. Svoje financie môžeme mat' neustále pod kontrolou v digitálnom prostrední, čo predstavuje nie len ekologickú inováciu (minimalizácia papierov), ale $\mathrm{v}$ tomto prípade aj spoločensky zodpovednú inováciu $\mathrm{v}$ rámci zeleného bankovníctva, kedy bankové operácie môžeme vykonávat' v bezpečí domova.

Avšak, ako poukazujú aj výsledky uvedeného prieskumu (viac ako $39 \%$ respondentov uprednostní návštevu na kamennú pobočke banky), zelené bankovníctvo sa stretáva $\mathrm{s}$ bariérami [18], ked’že práve inovácie v bankovom sektore, ktoré sú tlačené technológiou často narážajú na problém ich prijatia zákazníkmi a ich adaptácia u zákazníkov ma dlhší 
charakter ako pri inováciách t’ahaných dopytom. Mnohí klienti dodnes nemajú ani mailové adresy a majú nízku digitálnu gramotnost' čo predstavuje rovnako bariéry zeleného bankovníctva.

Bankový sektor však nepredstavuje iba sektor, ktorý sa zameriava v rámci ekologických inovácií iba na maximalizáciu eliminácie papierov a pretransformovanie týchto operácií do digitálneho prostredia, ale ako uvádza Daniel Acs [18] zo záujmového združenia Bioeconomy Cluster, podl'a ktorého sú práve banky tými inštitúciami, ktoré dokážu podporit' ekologicky významné projekty a naplnit' tak myšlienku zeleného financovania projektov založených na princípoch trvalo udržatel'ného rozvoja podporujúc tak ekologické inovácie. Čo rovnako poukazuje na skutočnost', že zelené bankovníctvo, rozvoj a podpora ekologických inovácií má vo svete svoje dôležité miesto.

\section{Záver}

Aj napriek, že v počiatočnej fáze uvádzania inovácií na trh, majú tieto negatívny vplyv na hodnotu pre zákazníka, je nevyhnutné ich zavádzat' a v rámci ich životného cyklu ich podporovat' ich rozvoj, nakol'ko v budúcnosti ich význam môže byt' vysoký. Toto tvrdenie sa potvrdilo aj v súčasnosti, v čase pandémie COVID - 19, kedy inovácie, ktoré využívali iba odvážlivci, v čase pandémie sa stali bežnými aj pre odvážlivcov, skeptikov a tradicionalistov, t.j. využívanie inovácií sa zvýšilo. Svet a technológia sa neustále mení a napreduje, preto inovácie považujeme za výhodu. Preto ak už dnes banky disponujú rôznymi inováciami, do budúcna táto skutočnost' pre nich predstavuje výhodu.

\section{Literatúra}

[1] JOBS, S.: „Inovácia predstavuje rozdiel medzi lídrom a nasledovníkom.“ Zdroj: https://citaty-slavnych.sk/citaty/475815-steve-jobs-inovacia-predstavuje-rozdielmedzi-lidrom-a-nasled/?page $=2$

[2] MOLNÁR, P., DUPAL, A.: Manažment inovácií podniku: Manažment výrobkových inovácií v podniku. 1. vyd. Bratislava: EKONÓM, 2002. 170 s. ISBN 80-225-1642-2.

[3] TROMMSDORFF, V., STEINHOFF, F.: Marketing inovácií. 1. vyd. Praha: C. H. Beck, 2009. 291 s. ISBN 978-80-7400-092-8.

[4] ČIMO, J.: Inovačný manažment. 1. vyd. Bratislava: EKONÓM, 2010. 226 s. ISBN 97880-225-3057-6.

[5] ARUNDEL, A., KEMP. R.: Measuring eco-innovation. (Working Paper Series). United Nations University - Maastricht Economic and social Research and training centre on Innovation and Technology. 2009

[6] OECD: Sustainable Manufacturing and Eco-Innovation Framework, Practices and Measurement, 2009. [online] OECD: Paris. [cit. 2019-01-09] http://www.oecd.org/sti/innovationinsciencetechnologyandindustry/ 43423689.pdf.

[7] LOUČANOVÁ, E.: Inovačné analýzy a stratégie. I. vydanie. Zvolen: Technická univerzita vo Zvolene, 2016. 149 s. ISBN 978-80-228-2899-4.

[8] KRNÁČOVÁ, P., LESNÍKOVÁ P.: Kano model spokojnosti zákazníka v neziskovom sektore. In Vedecké state Obchodnej fakulty 2012. Eds. P. Drábik a kol. Bratislava: EKONÓM, 2012, s. 368 - 382. ISBN 978-80-225-3452-9

[9] RICHTEROVÁ, K.: Marketingový výskum. Ekonóm, 2002. 379 s. ISBN 978-80-2251493-4.

[10] Chen, L.-S. a kol.: C-Kano model: a Novel Approach for Discovering Attractive Quality Elements. In Total Quality Management. ISSN 1478-3371, 2010, Vol. 21, No. 11, p. 1189-1214.

[11] SLÁVIK, Š, 1999. Strategické riadenie podniku, SPRINT, 1999. ISBN 80-225-0893-4. 
[12]LOUČANOVÁ, E., HYBSKÁ, P.: Databáza údajov a ich matematicko-štatistické vyhodnotenie a charakteristika výsledkov, 2020.

[13]LOUČANOVÁ, E.: Vnímanie ekologických inovácií na Slovensku: Perception of environmental innovation in Slovakia. In Ekonomické spektrum: scientific journal about economy and economics, 2019, 14 (1), ISSN 1336-9105.

[14] VEBER, J. a kol.: Management inovací. I. vydanie. Praha: Management Press, 2016. 288 s. ISBN 978-80-7261-423-3.

[15] ŠTOFKOVÁ, K.: Konkurencieschopnost’ podnikov v podmienkach európskej integrácie a globalizácie. In: Pošta, Telekomunikácie a Elektronický obchod [elektronický zdroj] : elektronický vedecký časopis zameraný na problematiku poštových a telekomunikačných podnikov a oblast' elektronického obchodovania. - ISSN 1336-8281. - 2013. - Roč. 8, č. 1 (2013), online, s. 71-74.

[16] RUDY, R.: Innovation methods in structures of production systems designing In: Ovidius University Annual Scientific Journal. Vol. 11, no. 1 2009, p. 15-18. - ISSN 1224-1776.

[17]BAČIŠIN, V. 2010. Modely inovačného procesu a súvislost' s financovaním. 2010. Bratislava. ISSN $1336 \quad$ - 5711. Dostupné na internete: http://www.derivat.sk/index.php?PageID=1776.

[18] NEXTECH, 2019. Svet miliardového biznisu v podobe bankovníctva a poist'ovníctva sa nám vd’aka Fintech a Insurtech mení priamo pred očami. Dostupné na internete: https://www.pcrevue.sk/a/Svet-miliardoveho-biznisu-sa-v-podobe-bankovnictva-aA0poistovnictva-meni

\section{Grantová podpora}

VEGA 1/0674/19 Návrh modelu implementácie ekologických inovácií do inovačného procesu podnikatel'ských subjektov na Slovensku pre zvýšenie ich výkonnosti. 